Check for updates

Cite this: RSC Adv., 2017, 7, 54779

Received 6th September 2017

Accepted 22nd November 2017

DOI: 10.1039/c7ra09917g

rsc.li/rsc-advances

\section{Synergistic catalysis of nano-Pd and nano rare- earth oxide/AC: complex nanostructured catalysts fabricated by a photochemical route for selective hydrogenation of phenol $\dagger$}

\begin{abstract}
Yanji Zhang, Jicheng Zhou (D)* and Jiaqi Si
Cyclohexanone is an important industrial intermediate in the manufacture of polyamides in the chemical industry, but direct selective hydrogenation of phenol to cyclohexanone under mild conditions to achieve both high conversion and selectivity is a challenge. Here we report novel complex nanostructured catalysts $\mathrm{Pd} / \mathrm{a}-\mathrm{CeO}_{2} / \mathrm{AC}$ and $\mathrm{Pd} / \mathrm{a}-\mathrm{La}_{2} \mathrm{O}_{3} / \mathrm{AC}$ prepared by a photochemical route. These catalysts were characterized by XRD, BET, TEM, $\mathrm{H}_{2}-T P R$ and XPS. The results showed that $\mathrm{Pd}$ nanoparticles were well-dispersed on $\mathrm{CeO}_{2} / \mathrm{AC}$ or $\mathrm{La}_{2} \mathrm{O}_{3} / \mathrm{AC}$, and the complex nanostructured catalysts exhibit a synergistic effect between nano-Pd and nano- $\mathrm{La}_{2} \mathrm{O}_{3} / \mathrm{AC}$ or nano- $\mathrm{CeO}_{2} / \mathrm{AC}$. These catalysts had an excellent catalytic performance for the hydrogenation of phenol, achieved $100 \%$ conversion and a selectivity higher than $96 \%$ within $3 \mathrm{~h}$ at $70{ }^{\circ} \mathrm{C}$ and $0.7 \mathrm{MPa} \mathrm{H}_{2}$ pressure. The results indicated that the remarkable performance may result from the synergistic effect between active component Pd and rareearth oxide, their complex nanostructured properties and the high dispersion of Pd particles on the large surface area. Furthermore, this work revealed synergistic catalysis of nano-metal Pd and nano rare-earth oxide and opened a new direction of synergistic catalysis of nanostructured catalysts.
\end{abstract}

\section{Introduction}

Cyclohexanone is an important intermediate in the production of caprolactam, which is used in the manufacture of nylon 6 and nylon 66. ${ }^{1}$ In general, cyclohexanone can be obtained from cyclohexane oxidation or phenol hydrogenation. ${ }^{2}$ The former route requires high temperatures and high pressures and generates a large number of byproducts, but low conversion and high energy consumption. ${ }^{3}$ Therefore, selective hydrogenation of phenol to cyclohexanone is an important chemical process that has been extensively studied to date. ${ }^{4,5}$ In the hydrogenation of phenol, cyclohexanone is generally obtained through a one-step or a two-step process. In the two-step procedure, phenol is first hydrogenated to cyclohexanol and then cyclohexanol is dehydrogenated to cyclohexanone at high temperature. ${ }^{6}$ In one-step, the selective hydrogenation of phenol directly into cyclohexanone, ${ }^{7}$ however, cyclohexanone can be further hydrogenated to cyclohexanol easily, so it is extremely necessary to prepare high selectivity and conversion catalysts. In recent years, supported Pd-based catalysts have been widely used for the selective hydrogenation of phenol to cyclohexanone, ${ }^{8}$ such

Key Laboratory of Green Catalysis and Chemical Reaction Engineering of Hunan Province, School of Chemical Engineering, Xiangtan University, Xiangtan 411105, Hunan Province, China. E-mail: zhoujicheng2012@126.com

$\dagger$ Electronic supplementary information (ESI) available. See DOI: 10.1039/c7ra09917g as $\mathrm{Pd} / \mathrm{C},{ }^{9} \mathrm{Pd} / \mathrm{MCM}-41,{ }^{10} \mathrm{Pd}-\mathrm{Al}_{2} \mathrm{O}_{3},{ }^{11} \mathrm{Pd} / \mathrm{ZrO}_{2},{ }^{12} \mathrm{Pd} / \mathrm{Ce}-\mathrm{AlO}_{x}$ (ref. 13) and so on. All of those catalysts indicated that $\mathrm{Pd}$ is an excellent metal catalyst for phenol hydrogenation. However, to achieving both excellent conversion $(\geq 80 \%)$ and high selectivity $\left(\geq 90 \%\right.$ ) under mild conditions is still a challenging problem. ${ }^{\mathbf{1 4}}$

Notably, Han Buxing and his co-worker ${ }^{15}$ reported that a complete phenol conversion with $>99.9 \%$ selectivity to cyclohexanone could be achieved on a dual-supported Pd-Lewis acid catalyst in sc- $\mathrm{CO}_{2}$, while the conditions is so sophisticated (supercritical carbon dioxide as solvent, which requires high $\mathrm{H}_{2}$ and $\mathrm{CO}_{2}$ pressures $>7.0 \mathrm{MPa}$ ). Most recently, Wang Yong and coworks designed a kind of carbon nitride material as support to prepare Pd-based catalysts, ${ }^{\mathbf{1 6}}$ which achieved both excellent conversion and selectivity in the hydrogenation of phenol in aqueous media. Nevertheless, the preparation of the mpg- $\mathrm{C}_{3} \mathrm{~N}_{4}$ and/or CN- $x$ was complicated and involved the use of $\mathrm{NH}_{4} \mathrm{HF}_{2}$ or $\mathrm{HF}$ which are hazardous. Zhaoyin $\mathrm{Hou}^{17}$ prepared a Amberlyst-45 palladium catalyst ( $\mathrm{Pd} / \mathrm{A}-45)$, achieved $89 \%$ cyclohexanone selectivity and $100 \%$ phenol conversion at $100{ }^{\circ} \mathrm{C}$ and $1 \mathrm{MPa} \mathrm{H}_{2}$ pressure in water. They think the good performance of $\mathrm{Pd} / \mathrm{A}-45$ can be attributed to its strong acidity enhance the desorption of phenoxy species. On the other hand, Chen and coworks ${ }^{18-21}$ utilized polymer-functionalized CNF, hydroxyapatitebound and/or ionic liquid-like copolymer to stabilize Pd, and the as-prepared catalysts have been proven to be efficient for phenol hydrogenation. However, the preparation of these 
catalysts required many expensive polymers and had the disadvantage of high preparation cost. In conclusion, although a few catalysts show a decent activity under an appropriate conditions, either the harsh reaction conditions, the low cyclohexanone selectivity $(<90 \%)$ or the complicated method to prepare catalysts. Therefore, it is necessary to use a facile method to prepare catalyst for high efficient selective hydrogenation of phenol.

Recently, rare earth oxide has been great interest in the use of catalytic reaction due to its unique characteristics. Especially, the $\mathrm{CeO}_{2}$ and $\mathrm{La}_{2} \mathrm{O}_{3}$ are the most widely used. ${ }^{22,23} \mathrm{CeO}_{2}$ has a good performance of stockpile and release oxygen, it can not only enhance the catalytic activity but also improve thermostability. ${ }^{24,25} \mathrm{La}_{2} \mathrm{O}_{3}$ has a lot of attractive properties for applications such as catalysts, high $\mathrm{k}$ gate dielectric material and optical filters. ${ }^{26}$ Even so, they are low activity for used as catalyst directly. But when they combined with noble metal, it could influence the catalytic performance. Salvatore Scirè ${ }^{27}$ studied the gas-phase phenol hydrogenation reaction over $\mathrm{Pd} / \mathrm{CeO}_{2}$ (40\% conversion, $92 \%$ selectivity) and $\mathrm{Pd} / \mathrm{La}_{2} \mathrm{O}_{3}$ (35\% conversion, $95 \%$ selectivity) at $160{ }^{\circ} \mathrm{C}$. The groups of Inagaki ${ }^{28}$ studied the reaction in the vapor phase over $\mathrm{Pd} / \mathrm{CeO}_{2}$ at $180{ }^{\circ} \mathrm{C}(80 \%$ conversion, $50 \%$ selectivity). However, the impact of the interaction between the metal oxide and noble metal on the catalytic performance of these catalysts has not been discussed. In addition, these catalysts has not achieve both excellent conversion and high selectivity simultaneously.

The utilization efficiency of noble metals (Pt, Au, Pd) in conventional supported catalysts is far less than satisfactory. Recently, research has been reported that the metal with higher dispersity, many of the metal atoms are present at a surface, available for catalysis and offer the efficiency. Flytzani-Stephanopoulos et al..$^{29-31}$ showed that atomically dispersed Au or Pt cations exhibited excellent catalytic activity for water-gas shift reaction, while Au or Pt particles had no chemical action. Another solution of the significantly reducing the use of precious metal, preparation of support single-atom catalysts (SAC), was proposed by Zheng and coworkers. ${ }^{32-34} \mathrm{We}$ proposed a novel strategy to utilize noble metal efficiently, and prepared a novel complex nanostructured catalyst $\mathrm{Au@TiO}{ }_{2} /$ MCM-41 and $\mathrm{Au} @ \mathrm{TiO}_{2} / \mathrm{MCM}-22$ by photochemical route, these catalysts exhibited excellent activity and chemical stability for cyclohexane oxidation. ${ }^{35-37}$ Herein, we used a novel strategy to prepare a complex nanostructured catalyst, which combined nano-metals with nano-semiconductor to fabricate a novel nano-Pd complex nanostructured catalyst $\mathrm{Pd} /$ (a)- $\mathrm{Me}_{x} \mathrm{O}_{y} / \mathrm{AC}\left(\mathrm{Me}_{x} \mathrm{O}_{y}: \mathrm{CeO}_{2}\right.$ or $\left.\mathrm{La}_{2} \mathrm{O}_{3}\right)$ by photochemical route. These complex catalysts were characterized by XRD, BET, TEM and XPS, and employed in the selective hydrogenation of phenol to cyclohexanone at low temperature and $\mathrm{H}_{2}$ pressure in the liquid phase. These catalysts exhibited a higher activity and selectivity to cyclohexanone, the remarkable catalytic performance could be ascribed to the synergistic effect between Pd nanoparticles and nano-semiconductor $\left(\mathrm{CeO}_{2}\right.$ or $\mathrm{La}_{2} \mathrm{O}_{3}$ ), their complex nano-structured properties and the large contact surface.

\section{Experimental}

\subsection{Catalyst preparation}

Pretreatment of activated carbon with acid. A commercial activated carbon (AC) made from coconut shells (Fujian Xinsen Carbon Co. Ltd.) was pretreated with $\mathrm{HNO}_{3}(10 \%)$ under refluxing at $60{ }^{\circ} \mathrm{C}$ for $2 \mathrm{~h}$. Then the $\mathrm{AC}$ were cooled to room temperature, washed to neutrality with distilled water. Finally, the $\mathrm{AC}$ were dried at $120^{\circ} \mathrm{C}$.

Preparation of composite support $\mathrm{CeO}_{2} / \mathrm{AC}$. The synthesis of $\mathrm{CeO}_{2} / \mathrm{AC}$ was adapted from the method of El-Shall. ${ }^{38} \mathrm{Ce}\left(\mathrm{NO}_{3}\right)_{3^{-}}$ $\cdot 6 \mathrm{H}_{2} \mathrm{O}(1.46 \mathrm{~g})$ dissolved in ethanol $(120 \mathrm{~mL})$, while stirring, add the pre-processed $\mathrm{AC}(5 \mathrm{~g})$ in it, $1 \mathrm{~mol} \mathrm{~L}^{-1} \mathrm{NaOH}$ was added dropwise until the $\mathrm{pH}$ of the resulting solution was 10, put the solution in the microwave with the power was set $214 \mathrm{~W}$ for $10 \mathrm{~min}$ (on for $10 \mathrm{~s}$, off for $20 \mathrm{~s}$ ). After cooled down to room temperature, washed with distilled water and ethanol then left to dry at $120{ }^{\circ} \mathrm{C}$ for $12 \mathrm{~h}$. The preparation of $\mathrm{CeO}_{2}$ was same as above, just not add the AC.

Preparation of composite support $\mathbf{L a}_{2} \mathrm{O}_{3} / \mathrm{AC}$. In a typical synthesis, $\mathrm{La}\left(\mathrm{NO}_{3}\right)_{2} \cdot n \mathrm{H}_{2} \mathrm{O}(0.554 \mathrm{~g})$ dissolved in distilled water $(120 \mathrm{~mL})$, while stirring, add the pre-processed AC $(5 \mathrm{~g})$ in it, $0.5 \mathrm{~mol} \mathrm{~L}^{-1} \mathrm{NH}_{4} \mathrm{HCO}_{3}$ was added dropwise until the $\mathrm{pH}$ of the resulting solution was 7.0, put the solution in the microwave with the power was set $400 \mathrm{~W}$ for $16 \mathrm{~min}$ (on for $30 \mathrm{~s}$, off for $30 \mathrm{~s}$ ). After filtrating, washing and dry at $70^{\circ} \mathrm{C}$ for $4 \mathrm{~h}$, finally achieved composite support $\mathrm{La}_{2} \mathrm{O}_{3} / \mathrm{AC}$ after calcined at $550{ }^{\circ} \mathrm{C}$ for $2 \mathrm{~h}$. The preparation of $\mathrm{La}_{2} \mathrm{O}_{3}$ was same as above, just not add the AC.

The obtained $\mathrm{CeO}_{2} / \mathrm{AC}$ and $\mathrm{La}_{2} \mathrm{O}_{3} / \mathrm{AC}$ composites were denoted as $x \mathrm{CeO}_{2} / \mathrm{AC}$ and $x \mathrm{La}_{2} \mathrm{O}_{3} / \mathrm{AC}$, where $x$ represents the $\mathrm{CeO}_{2} / \mathrm{AC}$ and $\mathrm{La}_{2} \mathrm{O}_{3} / \mathrm{AC}$ loading by weight.

Synthesis of Pd/@-Me $\mathrm{O}_{\boldsymbol{y}} / \mathrm{AC}$. All Pd catalysts were prepared by photochemical route with a 1-3 wt\% Pd loading relative to the mass of the support. Take an example of $\mathrm{Pd} / @-\mathrm{CeO}_{2} / \mathrm{AC}$ : asprepared $\mathrm{CeO}_{2} / \mathrm{AC}(0.582 \mathrm{~g})$ was added in distilled water $(100 \mathrm{~mL})$ and methanol $(5 \mathrm{~mL})$ mix solution, add the $\mathrm{H}_{2} \mathrm{PdCl}_{4}$ $\left(1.5 \mathrm{~mL}, 0.012 \mathrm{~g} \mathrm{~mL}^{-1}\right)$ in it, ultrasonic dispersion for 30 minutes, then ultraviolet lamp for $10 \mathrm{~h}$. Finally, the sample was separated by filtration, washed several times by distilled water up to $\mathrm{pH}=7$, dried in a vacuum oven at $80{ }^{\circ} \mathrm{C}$ for $10 \mathrm{~h}$. The preparation of $\mathrm{Pd} / @-\mathrm{La}_{2} \mathrm{O}_{3} / \mathrm{AC}, \mathrm{Pd} / \mathrm{AC}, \mathrm{Pd} / \mathrm{CeO}_{2}$ and $\mathrm{Pd} / \mathrm{La}_{2} \mathrm{O}_{3}$ were same as above, the only difference was to $\mathrm{CeO}_{2} / \mathrm{AC}$ with different supports. The procedures for preparing the $\mathrm{Pd} / @-\mathrm{CeO}_{2} / \mathrm{AC}$ or $\mathrm{Pd} / @-\mathrm{La}_{2} \mathrm{O}_{3} / \mathrm{AC}$ catalysts are graphically illustrated in Scheme 1.

Our previous work involving photocatalytic reduction of noble $\mathrm{Au}^{3{ }^{3-37}}$ the preparation process and condition was simple and mild, and the noble nanoparticles was uniform dispersed, this method is also applicable to reduction Pd. Photochemical deposition of Pd films or small particles on oxide substrates such as $\mathrm{TiO}_{2},{ }^{39,40}$ or graphene sheets/ZnO. ${ }^{41}$ Similarly, $\mathrm{CeO}_{2}$ is also an interesting material due to its unique redox properties as well as strong UV absorption at $\sim 400 \mathrm{~nm} .{ }^{42} \mathrm{La}_{2} \mathrm{O}_{3}$ is also a rare earth metal oxide and has similar chemical properties to $\mathrm{CeO}_{2}$. It is well known that a semiconductor can be excited and then generate electrons $\left(\mathrm{e}^{-}\right)$and holes $\left(\mathrm{h}^{+}\right)$in the conduction 


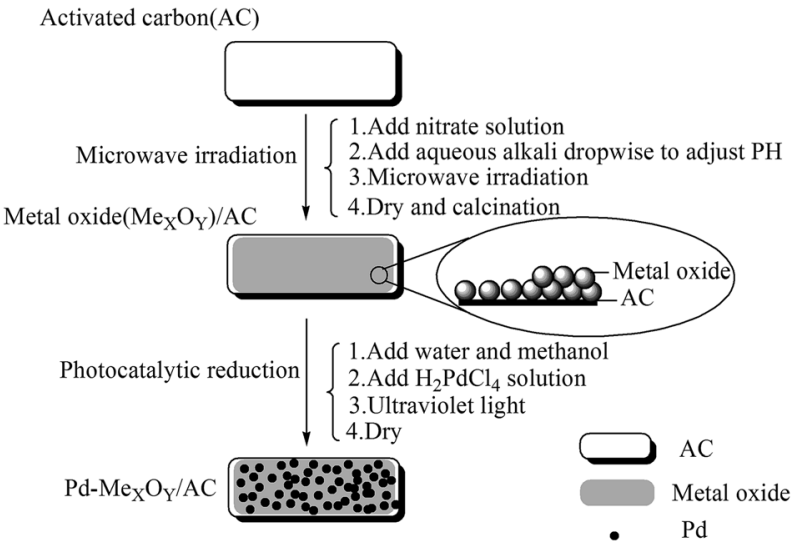

Scheme 1 Preparation of the $\mathrm{Pd} /\left(\mathrm{a}-\mathrm{CeO}_{2} / \mathrm{AC}\right.$ and $\mathrm{Pd} / \mathrm{a}-\mathrm{La}_{2} \mathrm{O}_{3} / \mathrm{AC}$ catalysts.

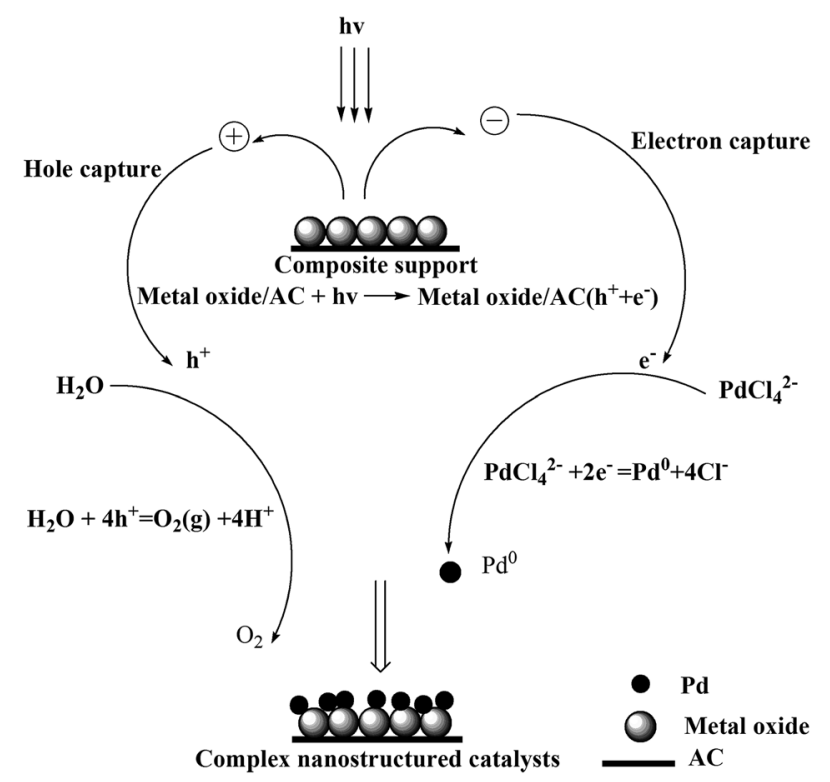

Scheme 2 Reaction mechanism of photocatalytic reduction method.

band (CB) and valence band (VB) if the energy of the photons of the incident light is larger than that of the band gap of the semiconductor. ${ }^{39}$ The reaction mechanism of photochemical route is in scheme 2. When composite support $\left(\mathrm{CeO}_{2} / \mathrm{AC}\right.$ or $\mathrm{La}_{2} \mathrm{O}_{3} / \mathrm{AC}$ ) absorbed ultraviolet, metal oxide semiconductor can be excited and then generate electrons $\left(\mathrm{e}^{-}\right)$and holes $\left(\mathrm{h}^{+}\right)$, forming electron-hole pairs. In the presence of methanol, the holes were scavenged, thus leaving the electrons to accumulate on the surface of the metal oxide semiconductor, the stored electrons were then transferred to the metal ions $\mathrm{Pd}^{2+}$ and reduced $\mathrm{Pd}^{2+}$ to form $\mathrm{Pd}$ on the surface of composite support.

\subsection{Catalyst characterization}

X-ray diffraction (XRD) of samples was obtained on a Rigaku D/ max-II/2500 X-ray powder diffractometer, $\mathrm{Cu} \mathrm{K} \alpha$ radiation was employed and the working voltage and current were $40 \mathrm{kV}$ and $30 \mathrm{~mA}$, respectively. Transmission electron microscope (TEM) images were obtained with a JEOL JEM-2100F at an acceleration voltage of $200 \mathrm{kV}$. X-ray photoelectron spectroscopy (XPS) was performing using ESCALAB 250Xi (Thermo) with $\mathrm{Al} \mathrm{K} \alpha$ radiation. Inductively coupled plasma-atomic emission spectrometry (ICP-AES) data were obtained using an Intrepid XSP (IRIS). The specific surface areas of the samples were calculated by the BET method by $\mathrm{N}_{2}$ adsorption-desorption with a NOVA-2200e volumetric desorption analyzer. Temperature-programmed reduction by hydrogen $\left(\mathrm{H}_{2}\right.$-TPR) was carried out on Chem Bet 3000 analyzer. All samples $(0.1 \mathrm{~g})$ were pretreated in the flow of Ar at $250{ }^{\circ} \mathrm{C}$ for 1 hour.

\subsection{Catalytic tests}

The typical procedure for hydrogenation of phenol was as follows: $0.1 \mathrm{~g}$ phenol, $0.353 \mathrm{~g}$ catalyst $(0.75 \mathrm{~mol} \% \mathrm{Pd}$ relative to phenol), and $20 \mathrm{~mL}$ solvent were placed in a autoclave. The autoclave was purged with $\mathrm{H}_{2}$ to remove the air 3 times. Then the reaction was stirred at $800 \mathrm{rpm}$ under $0.7 \mathrm{MPa}_{2}$ pressure until the temperature reached $70{ }^{\circ} \mathrm{C}$. After the end of the reaction, the autoclave was cooled to room temperature, then the products were analyzed using an Agilent 6890N GC (Fig. S1 $\dagger$ ) with an HP-5 $(30 \mathrm{~m} \times 0.32 \mathrm{~mm} \times 0.25 \mu \mathrm{m})$ capillary column and FID detector. The temperature of gasify room and detector were $250{ }^{\circ} \mathrm{C}$ and $280{ }^{\circ} \mathrm{C}$ respectively. The air at a constant flow of $400 \mathrm{~mL} \mathrm{~min}^{-1}$, the mixed gas $\mathrm{H}_{2}$ and $\mathrm{N}_{2}$ flow of $30 \mathrm{~mL} \mathrm{~min}{ }^{-1}$. The initial column temperature was fixed at $50{ }^{\circ} \mathrm{C}$ for $7 \mathrm{~min}$ and then increased to $180{ }^{\circ} \mathrm{C}$ at a rate of $60{ }^{\circ} \mathrm{C} \mathrm{min}{ }^{-1}$. The final temperature was maintained for $2 \mathrm{~min}$.

\section{Results and discussion}

\subsection{Characterization}

The XRD patterns of $\mathrm{AC}, \mathrm{CeO}_{2} / \mathrm{AC}, \mathrm{La}_{2} \mathrm{O}_{3} / \mathrm{AC}, \mathrm{Pd} / @-\mathrm{CeO}_{2} / \mathrm{AC}$ and $\mathrm{Pd} / @-\mathrm{La}_{2} \mathrm{O}_{3} / \mathrm{AC}$ catalysts were shown in Fig. 1. All samples present broadened peaks at about $2 \theta=25^{\circ}$ and $42^{\circ}$, which could be attributed to the AC support. Due to the high dispersion and low loading of $\mathrm{CeO}_{2}$ on the AC, just a very weak peaks at $2 \theta=56.1^{\circ}$. The diffraction peak at $2 \theta=31.3^{\circ}$ was attributed to $\mathrm{La}_{2} \mathrm{O}_{3}$. Four characteristic diffraction peaks of $\mathrm{Pd}$ were

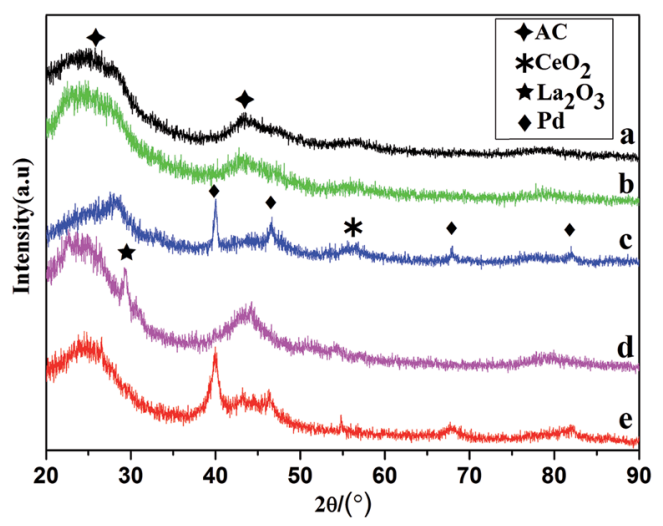

Fig. 1 XRD patterns of samples: (a) $\mathrm{AC}$ (b) $10 \% \mathrm{CeO}_{2} / \mathrm{AC}$, (c) $3 \% \mathrm{Pd} /$ (a-10\% $\mathrm{CeO}_{2} / \mathrm{AC}$, (d) $10 \% \mathrm{La}_{2} \mathrm{O}_{3} / \mathrm{AC}$ (e) $3 \% \mathrm{Pd} / \mathrm{a}-10 \% \mathrm{La}_{2} \mathrm{O}_{3} / \mathrm{AC}$. 
detected at $2 \theta=40.2^{\circ}, 46.6^{\circ}, 68.2^{\circ}$ and $82.2^{\circ}$, which were attributed to the (111), (200), (220) and (311) crystalline planes. Comparison with $\mathrm{La}_{2} \mathrm{O}_{3} / \mathrm{AC}$, the peaks attributed to $\mathrm{La}_{2} \mathrm{O}_{3}$ in XRD patterns of $\mathrm{Pd} / @-\mathrm{La}_{2} \mathrm{O}_{3} / \mathrm{AC}$ became very weak or disappeared, which result from the uniform mixture of $\mathrm{AC}$ with $\mathrm{La}_{2} \mathrm{O}_{3}$, because the strong mechanical and chemical effects of an ultrasound wave and ultraviolet lamp dispersed the precipitates immediately.

TEM and HRTEM images of 3\% Pd/@-10\% $\mathrm{CeO}_{2} / \mathrm{AC}$ and $3 \%$ $\mathrm{Pd} / @-10 \% \mathrm{La}_{2} \mathrm{O}_{3} / \mathrm{AC}$ were recorded and shown in Fig. 2. For 3\% $\mathrm{Pd} / @-10 \% \mathrm{CeO}_{2} / \mathrm{AC}$ (Fig. 2a), the Pd nanoparticles are evident as larger dark spots, while the $\mathrm{CeO}_{2}$ substrate is smaller, it was very clear that the Pd particles were dispersed mainly on the composite support. Particles are distribution analysis in Fig. 2b, which reveals that the particles are in the range of 5-30 nm with $13 \mathrm{~nm}$ as an average diameter. The result was consistent with the average particle size $13.77 \mathrm{~nm}$ that obtained from XRD by the Scherrer equation. Fig. 2c represents the HRTEM image of $3 \% \mathrm{Pd} / @-10 \% \mathrm{CeO}_{2} / \mathrm{AC}$, the lattice fringe with a $d$-spacing of $0.312 \mathrm{~nm}$ corresponds to the (111) plane of $\mathrm{CeO}_{2}$, and the distance of $0.223 \mathrm{~nm}$ (measured crystal DigitalMicrograph) corresponds to the (111) plane of Pd. Fig. 2d show the EDX data of $3 \% \mathrm{Pd} / @-10 \% \mathrm{CeO}_{2} / \mathrm{AC}$, the data indicate the presence of elemental constituents within the as-synthesized samples. For 3\% $\mathrm{Pd} / @-10 \% \mathrm{La}_{2} \mathrm{O}_{3} / \mathrm{AC}$ (Fig. 2e), the situation is different, the $\mathrm{Pd}$ nanoparticles was more smaller than 3\% $\mathrm{Pd} / @-10 \% \mathrm{CeO}_{2} /$ $\mathrm{AC}$, which resulted from the interaction between $\mathrm{Pd}$ and $\mathrm{La}_{2} \mathrm{O}_{3}$, because the Pd nanoparticles could be smaller when the sample contains $\mathrm{La}_{2} \mathrm{O}_{3}{ }^{43}$ The image revealed highly dispersed Pd with a mean size of $5.5 \mathrm{~nm}$ (Fig. 2f). Fig. $2 \mathrm{~g}$ represents the HRTEM image of $3 \% \mathrm{Pd} / @-10 \% \mathrm{La}_{2} \mathrm{O}_{3} / \mathrm{AC}$, the lattice fringe with a $d$ spacing of $0.297 \mathrm{~nm}$ corresponds to the (111) plane of $\mathrm{La}_{2} \mathrm{O}_{3}$, and the distance of $0.225 \mathrm{~nm}$ corresponds to the (111) plane of Pd. In Fig. 2h, we can also observe that the presence of elemental constituents within the as-synthesized samples.
The relevant physicochemical parameters of the AC, $10 \%$ $\mathrm{CeO}_{2} / \mathrm{AC}, 10 \% \mathrm{La}_{2} \mathrm{O}_{3} / \mathrm{AC}, 3 \% \mathrm{Pd} / \mathrm{Q}-10 \% \mathrm{CeO}_{2} / \mathrm{AC}$ and $3 \%$ $\mathrm{Pd} / @-10 \% \mathrm{La}_{2} \mathrm{O}_{3} / \mathrm{AC}$ were summarized in Table 1. The AC had a high specific surface area of $1418.6 \mathrm{~m}^{2} \mathrm{~g}^{-1}$, however, the specific surface area decreased to $1309.2 \mathrm{~m}^{2} \mathrm{~g}^{-1}$ and $1349.7 \mathrm{~m}^{2} \mathrm{~g}^{-1}$ after doping $\mathrm{CeO}_{2}$ and $\mathrm{La}_{2} \mathrm{O}_{3}$, respectively. The surface area decreased gradually with further loading of $\mathrm{Pd}$. Thus, the catalysts $3 \%$ $\mathrm{Pd} / @-10 \% \mathrm{CeO}_{2} / \mathrm{AC}$ and 3\% $\mathrm{Pd} / @-10 \% \mathrm{La}_{2} \mathrm{O}_{3} / \mathrm{AC}$ exhibit the surface area of $1138.1 \mathrm{~m}^{2} \mathrm{~g}^{-1}$ and $1349.7 \mathrm{~m}^{2} \mathrm{~g}^{-1}$, respectively. This indicated that the loading of metal oxide and Pd within the pores, which is consistent with the reports. ${ }^{44}$

XPS was performed on the $3 \% \mathrm{Pd} / @-10 \% \mathrm{CeO}_{2} / \mathrm{AC}$ and $3 \%$ $\mathrm{Pd} / @-10 \% \mathrm{La}_{2} \mathrm{O}_{3} / \mathrm{AC}$ catalysts and the results were shown in Fig. 3. From Fig. 3a, Pd, Ce, C, O and Pd, La, C, O were detected in two samples, respectively. Indicated the presence of $\mathrm{CeO}_{2}$ and $\mathrm{La}_{2} \mathrm{O}_{3}$ in $\mathrm{Pd} / @-\mathrm{CeO}_{2} / \mathrm{AC}$ and $\mathrm{Pd} / @-\mathrm{La}_{2} \mathrm{O}_{3} / \mathrm{AC}$, respectively. And Pd species was loaded on the composite support by photochemical route. In Fig. 3b, the Pd 3d XPS spectra of the two catalysts show four asymmetric broad peaks. Peaks detected at around $335.9 \mathrm{eV}$ and $341.1 \mathrm{eV}$ can be readily assigned to the $\operatorname{Pd} 3 \mathrm{~d}_{5 / 2}$ and $\mathrm{Pd} 3 \mathrm{~d}_{3 / 2}$ electronic states of $\mathrm{Pd}(0),{ }^{45}$ respectively. Compared with standard values (335 eV and $340.3 \mathrm{eV}$ ), the measured values are higher than their standard values, the electron move from $\mathrm{Pd}$ to $\mathrm{CeO}_{2}$, the dissociatively chemisorbed hydrogen on Pd may diffuse from Pd surface to $\mathrm{CeO}_{2}$ and reduce $\mathrm{Ce}^{4+}$ to $\mathrm{Ce}^{3+}$. That means the strong metal-support interaction between nano-Pd and nano- $\mathrm{CeO}_{2} / \mathrm{AC}$. Peaks at $337.1 \mathrm{eV}$ and $342.6 \mathrm{eV}$ correspond to the $\mathrm{Pd} 3 \mathrm{~d}_{5 / 2}$ and $\mathrm{Pd} 3 \mathrm{~d}_{3 / 2}$ electronic states of $\mathrm{Pd}(2+)$ species, respectively. The presence of $\mathrm{Pd}(2+)$ species was probably due to the interaction of Pd and surface adsorbed oxygen, which is beneficial for the enhancement of adherence of Pd on the support. ${ }^{46}$ The Ce $3 \mathrm{~d}$ XPS spectrum (Fig. 3c) consists of a spin orbit split doublet, the peaks located at $883.0 \mathrm{eV}, 887.2 \mathrm{eV}$ and $898.8 \mathrm{eV}$ represent the Ce $3 \mathrm{~d}_{5 / 2}$ and the peaks located at $901.6 \mathrm{eV}, 907.2 \mathrm{eV}$ and $917.1 \mathrm{eV}$ represent the
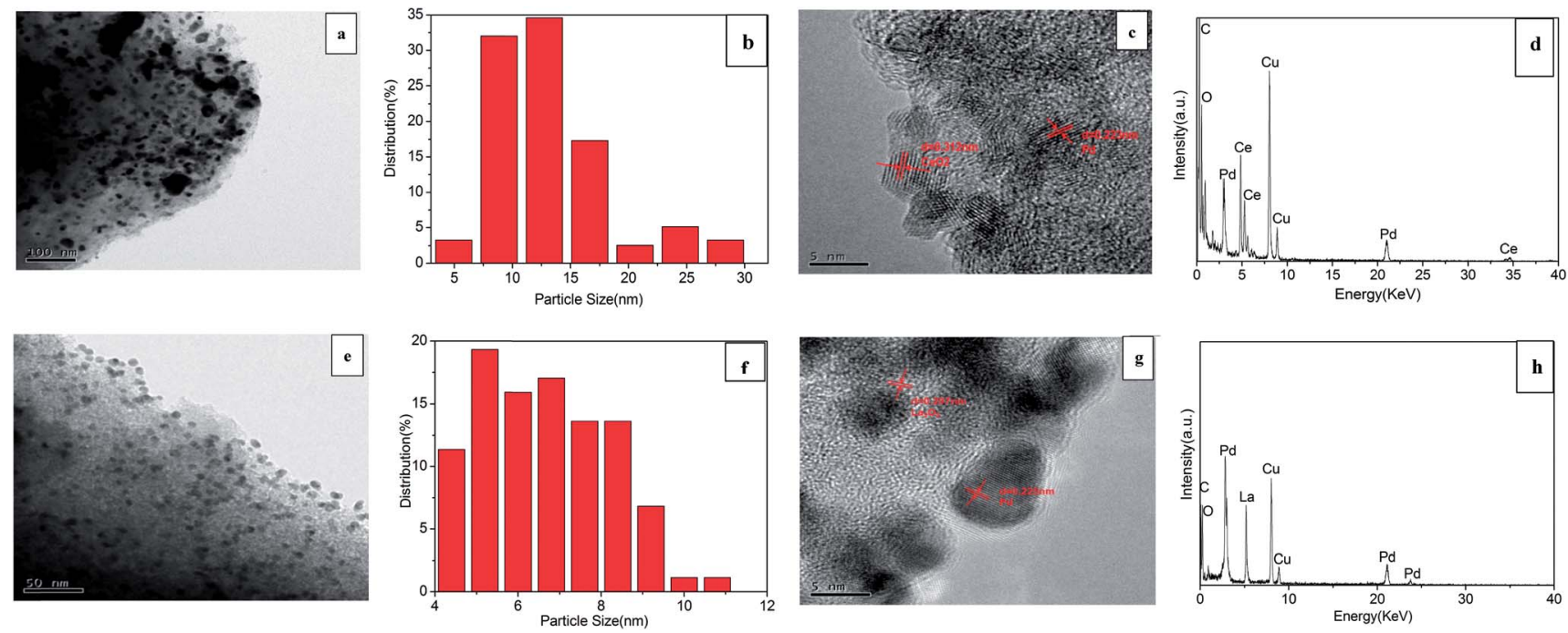

Fig. 2 (a) TEM image of $3 \% \mathrm{Pd} / \mathrm{a}-10 \% \mathrm{CeO}_{2} / \mathrm{AC}$, (b) size distribution of $\mathrm{Pd}$ on $3 \% \mathrm{Pd} / \mathrm{a}-10 \% \mathrm{CeO}_{2} / \mathrm{AC}$, (c) $\mathrm{HRTEM}$ image of $3 \% \mathrm{Pd} / \mathrm{a}-10 \% \mathrm{CeO} /$ $\mathrm{AC}$, (d) EDX spectrum of $3 \% \mathrm{Pd} / \mathrm{a}-10 \% \mathrm{CeO}_{2} / \mathrm{AC}$, (e) TEM image of $3 \% \mathrm{Pd} / \mathrm{a}-10 \% \mathrm{La}_{2} \mathrm{O}_{3} / \mathrm{AC}$, (f) size distribution of $\mathrm{Pd}$ on $3 \% \mathrm{Pd} / \mathrm{a}-10 \% \mathrm{La} 2 \mathrm{O} 3 / \mathrm{AC}$, (g) HRTEM image of $3 \% \mathrm{Pd} / \mathrm{a}-10 \% \mathrm{La}_{2} \mathrm{O}_{3} / \mathrm{AC}$, (h) EDX spectrum of $3 \% \mathrm{Pd} / \mathrm{a}-10 \% \mathrm{La}_{2} \mathrm{O}_{3} / \mathrm{AC}$. 
Table 1 Relevant physicochemical parameters of supports and Pd catalysts

\begin{tabular}{|c|c|c|c|c|c|}
\hline \multirow[b]{2}{*}{ Entry } & \multirow[b]{2}{*}{ Catalysts } & \multirow[b]{2}{*}{ Surface area ${ }^{a}\left(\mathrm{~m}^{2} \mathrm{~g}^{-1}\right)$} & \multicolumn{2}{|c|}{ Pd loading (wt\%) } & \multirow[b]{2}{*}{ Pd particle size ${ }^{c}(\mathrm{~nm})$} \\
\hline & & & Theoretical & Experimental $^{b}$ & \\
\hline 1 & $\mathrm{AC}$ & 1418.6 & - & - & - \\
\hline 2 & $10 \% \mathrm{CeO}_{2} / \mathrm{AC}$ & 1309.2 & - & - & - \\
\hline 3 & $3 \% \mathrm{Pd} /\left(\mathrm{Q}-10 \% \mathrm{CeO}_{2} / \mathrm{AC}\right.$ & 1138.1 & 3 & 2.985 & $5-30$ \\
\hline 4 & $10 \% \mathrm{La}_{2} \mathrm{O}_{3} / \mathrm{AC}$ & 1410.4 & - & - & - \\
\hline 5 & $3 \% \mathrm{Pd} / @-10 \% \mathrm{La}_{2} \mathrm{O}_{3} / \mathrm{AC}$ & 1349.7 & 3 & 2.977 & $4-12$ \\
\hline
\end{tabular}
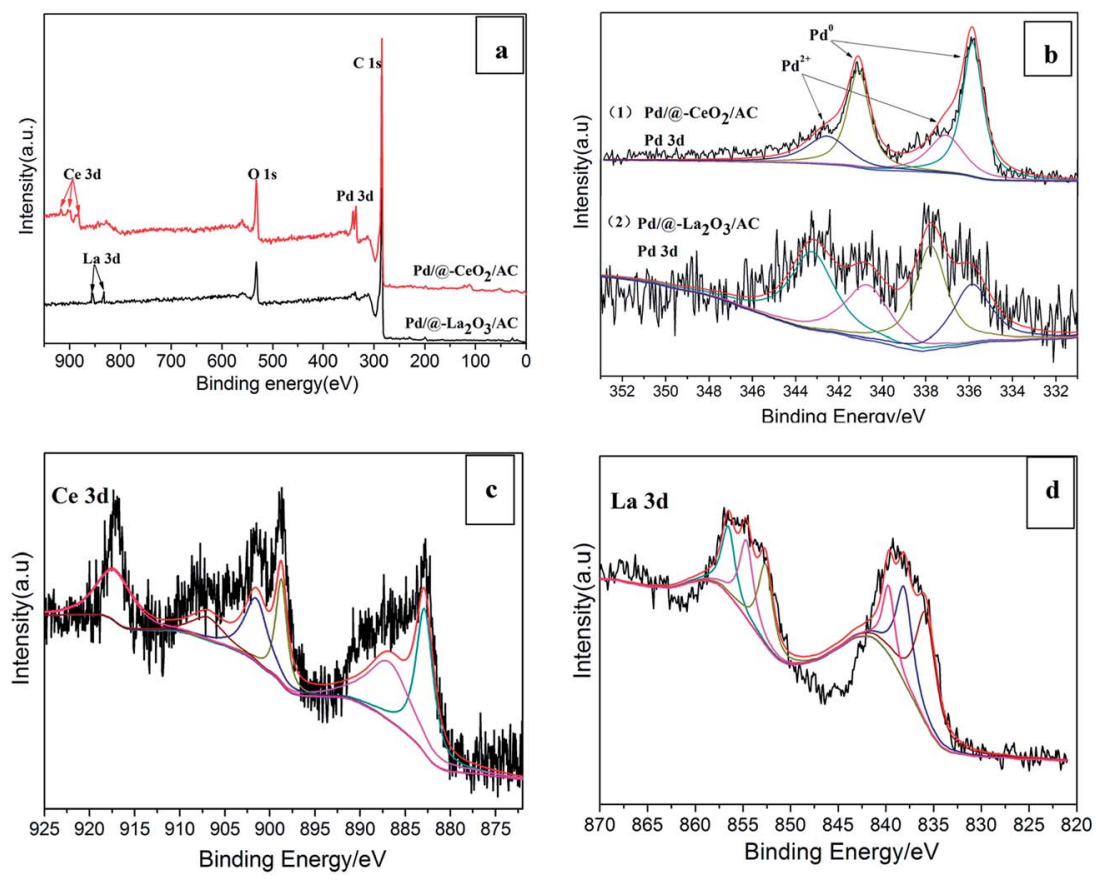

Fig. 3 (a) XPS scans survey for $3 \% \mathrm{Pd} / \mathrm{a}-10 \% \mathrm{CeO}_{2} / \mathrm{AC}$ and $3 \% \mathrm{Pd} / \mathrm{a}-10 \% \mathrm{La}_{2} \mathrm{O}_{3} / \mathrm{AC}$, (b) Pd $3 \mathrm{~d}$ XPS spectra of $3 \% \mathrm{Pd} / \mathrm{a}-10 \% \mathrm{CeO} / \mathrm{AC}$ and $3 \% \mathrm{Pd} /$ (a-10\% $\mathrm{La}_{2} \mathrm{O}_{3} / \mathrm{AC}$, (c) Ce $3 \mathrm{~d}$ XPS spectra, (d) La 3d XPS spectra.

Ce $3 \mathrm{~d}_{3 / 2}$ peaks. The peaks at $883.0 \mathrm{eV}, 898.8 \mathrm{eV}, 907.2 \mathrm{eV}$ and $917.1 \mathrm{eV}$ could be attributed to $\mathrm{Ce}^{4+}$ oxidation states while the peaks at $887.2 \mathrm{eV}$ and $901.6 \mathrm{eV}$ emanate from $\mathrm{Ce}^{3+}$ oxidation states of cerium. ${ }^{47,48}$ Hence, from the XPS spectrum it was confirmed that the sample contains mixed oxidation states $\left(\mathrm{Ce}^{4+}\right.$ and $\left.\mathrm{Ce}^{3+}\right)$. The La 3d XPS spectrum was shown in Fig. 3d, the peaks located at $835.8 \mathrm{eV}, 838.2 \mathrm{eV}$ and $839.8 \mathrm{eV}$ represent the $\mathrm{La} 3 \mathrm{~d}_{5 / 2}$ and the peaks located at $852.6 \mathrm{eV}, 854.6 \mathrm{eV}$ and $856.5 \mathrm{eV}$ represent the $\mathrm{La} 3 \mathrm{~d}_{3 / 2}$ peaks. And the peaks at $835.8 \mathrm{eV}$ and $838.2 \mathrm{eV}$ could be attributed to $\mathrm{La}^{3+}{ }^{49}$

\subsection{Hydrogenation of phenol}

The Pd complex nanostructured catalysts $\mathrm{Pd} / @-\mathrm{CeO}_{2} / \mathrm{AC}$ and $\mathrm{Pd} /$ @- $\mathrm{La}_{2} \mathrm{O}_{3} / \mathrm{AC}$ were first applied to selective hydrogenation of phenol. For comparison, the $\mathrm{CeO}_{2} / \mathrm{AC}, \mathrm{La}_{2} \mathrm{O}_{3} / \mathrm{AC}, \mathrm{Pd} / \mathrm{AC}, \mathrm{Pd} /$ $\mathrm{La}_{2} \mathrm{O}_{3}$ and $\mathrm{Pd} / \mathrm{CeO}_{2}$ were also used as reference catalysts, the results are shown in Table 2 . As we can see, only metal oxide supported on AC samples $\mathrm{CeO}_{2} / \mathrm{AC}$ or $\mathrm{La}_{2} \mathrm{O}_{3} / \mathrm{AC}$ have no catalytic activity (Table 2, entry 5 and 6). Obviously, the Pd played a major role in reaction. Whereas these reference catalysts $3 \% \mathrm{Pd} / \mathrm{CeO}_{2}$ (Table 2, entry 3 ) and $3 \% \mathrm{Pd} / \mathrm{La}_{2} \mathrm{O}_{3}$ (Table 2 , entry 4) almost no catalytic activity, with a phenol conversion of less than $10 \%$, the selectivity of cyclohexanone were over than 99\%. The 3\% Pd/AC (Table 2, entry 1 ) catalyst have a better catalytic activity for selective hydrogenation of phenol, conversion of phenol could achieved to $76.6 \%$. Wang Yong et al. ${ }^{49}$ have reported that hydrogenation of phenol to cyclohexanone can achieve $2 \%$ phenol conversion and $100 \%$ cyclohexanone selectivity at $65{ }^{\circ} \mathrm{C}$ and $6 \mathrm{~h}$ in water with commercial $\mathrm{Pd} @ \mathrm{CeO}_{2}$ catalyst. Chen Jinzhu et al. ${ }^{18}$ achieve $55 \%$ phenol conversion and $89 \%$ cyclohexanone selectivity with $10 \% \mathrm{Pd} / \mathrm{AC}$ catalyst at $80{ }^{\circ} \mathrm{C}$ and $9 \mathrm{~h}$. Obviously, the activity of $\mathrm{Pd} / \mathrm{metal}$ oxide and $\mathrm{Pd} /$ AC catalysts were far less than satisfactory. See the complex nanostructured catalysts 3\% $\mathrm{Pd} / @-10 \% \mathrm{CeO}_{2} / \mathrm{AC}$ and $3 \% \mathrm{Pd} /$ (a)-10\% $\mathrm{La}_{2} \mathrm{O}_{3} / \mathrm{AC}$ catalysts (Table 2, entry 9 and 15), they exhibited remarkable catalytic performance for selective 
Table 2 Hydrogenation of phenol with the different catalysts ${ }^{a}$

\begin{tabular}{|c|c|c|c|c|}
\hline \multirow[b]{2}{*}{ Entry } & \multirow[b]{2}{*}{ Catalyst } & \multirow{2}{*}{$\begin{array}{l}\text { Phenol } \\
\text { conversion (\%) }\end{array}$} & \multicolumn{2}{|c|}{ Selectivity $^{b}(\%)$} \\
\hline & & & $\mathrm{C}=\mathrm{O}$ & $\mathrm{C}-\mathrm{OH}$ \\
\hline 1 & $3 \% \mathrm{Pd} / \mathrm{AC}$ & 76.62 & 96.21 & 3.79 \\
\hline $2^{c}$ & $10 \% \mathrm{Pd} / \mathrm{AC}$ & 55 & 89 & 11 \\
\hline 3 & $3 \% \mathrm{Pd} / \mathrm{CeO}_{2}$ & 4.50 & 99.20 & 0.8 \\
\hline 4 & $3 \% \mathrm{Pd} / \mathrm{La}_{2} \mathrm{O}_{3}$ & 8.15 & 100 & 0 \\
\hline 5 & $10 \% \mathrm{CeO}_{2} / \mathrm{AC}$ & 一 & - & - \\
\hline 6 & $10 \% \mathrm{La}_{2} \mathrm{O}_{3} / \mathrm{AC}$ & - & - & - \\
\hline 7 & 1\% Pd/@-10\% $\mathrm{CeO}_{2} / \mathrm{AC}$ & 32.6 & 96.30 & 3.70 \\
\hline 8 & $2 \% \mathrm{Pd} / @-10 \% \mathrm{CeO}_{2} / \mathrm{AC}$ & 70.00 & 95.80 & 4.20 \\
\hline 9 & 3\% Pd/@-10\% $\mathrm{CeO}_{2} / \mathrm{AC}$ & 97.22 & 96.32 & 3.68 \\
\hline 10 & 3\% Pd/@-5\% $\mathrm{CeO}_{2} / \mathrm{AC}$ & 72.12 & 96.91 & 3.09 \\
\hline 11 & $3 \% \mathrm{Pd} / @-2 \% \mathrm{CeO}_{2} / \mathrm{AC}$ & 66.73 & 97.14 & 2.86 \\
\hline 12 & $3 \% \mathrm{Pd} / @-1 \% \mathrm{CeO}_{2} / \mathrm{AC}$ & 60.90 & 96.93 & 3.07 \\
\hline 13 & 1\% Pd/@-10\% $\mathrm{La}_{2} \mathrm{O}_{3} / \mathrm{AC}$ & 10.98 & 100 & 0 \\
\hline 14 & $2 \% \mathrm{Pd} / @-10 \% \mathrm{La}_{2} \mathrm{O}_{3} / \mathrm{AC}$ & 49.24 & 97.12 & 2.88 \\
\hline 15 & $3 \% \mathrm{Pd} / @-10 \% \mathrm{La}_{2} \mathrm{O}_{3} / \mathrm{AC}$ & 100 & 96.82 & 3.18 \\
\hline 16 & $3 \% \mathrm{Pd} / @-5 \% \mathrm{La}_{2} \mathrm{O}_{3} / \mathrm{AC}$ & 96.52 & 97.07 & 2.93 \\
\hline 17 & $3 \% \mathrm{Pd} / @-2 \% \mathrm{La}_{2} \mathrm{O}_{3} / \mathrm{AC}$ & 88.08 & 97.16 & 2.84 \\
\hline 18 & $3 \% \mathrm{Pd} / @-1 \% \mathrm{La}_{2} \mathrm{O}_{3} / \mathrm{AC}$ & 79.69 & 97.35 & 2.65 \\
\hline
\end{tabular}

${ }^{a}$ Reaction conditions: phenol $(0.1 \mathrm{~g}), n(\mathrm{Pd}): n($ phenol $)=0.75 \%, \mathrm{CH}_{2} \mathrm{Cl}_{2}$ $(20 \mathrm{~mL}), 70{ }^{\circ} \mathrm{C}, 3 \mathrm{~h}, 0.7 \mathrm{MPa} \mathrm{H}_{2} \cdot{ }^{b} \mathrm{C}=\mathrm{O}$ indicates cyclohexanone and $\mathrm{C}-$ $\mathrm{OH}$ indicates cyclohexanol. ${ }^{c}$ Reaction conditions: phenol $(40 \mathrm{mg})$, $5 \mathrm{~mol} \%$ Pd relative to phenol, $\mathrm{H}_{2} \mathrm{O}(3 \mathrm{~mL}), 80{ }^{\circ} \mathrm{C}, 9 \mathrm{~h}, 0.1 \mathrm{MPa}_{2} \cdot{ }^{18}$

hydrogenation of phenol, conversion of phenol were achieved up to $100 \%$, selectivity of cyclohexanone were higher than $96 \%$. According to the above results, the complex nanostructured catalysts showed a high activity because of the synergistic effect between metal nanoparticles and nano-semiconductors support, which enhanced effect of electronic promote the excellent charge transfer, promoted the synthesis of cyclohexanone and increase its selectivity. Then, the nature of the support plays an important role on activity and selectivity of Pd catalysts, because it has a large specific surface area and the add of Ce or La could increase the alkaline of catalyst, ${ }^{27,50-52}$ which provided a large enough place for the hydrogenation of phenol and avoid the co-planar adsorption of phenol, thus improved the selectivity of cyclohexanone. These results indicated that the Pd complex nanostructured catalysts have superiority catalytic activity.
The loading of metal oxide has a great influence on the structure and catalytic performances of the complex nanostructured catalyst. Only Pd nanoparticles have been equably anchored on the nano- $\mathrm{CeO}_{2}$ or nano- $\mathrm{La}_{2} \mathrm{O}_{3}$ film layer, which was spread on the high specific surface AC, these complex nanostructured Pd catalysts exhibit synergistic catalysis and remarkable catalytic performances for the hydrogenation reaction of phenol. According to principles of the spontaneous monolayer distribution, metal oxide would disperse on the support at the state of the spontaneous monolayer distribution, when the content of metal oxide is less than a certain threshold and surface area of the support is large enough, so an appropriate amount of $\mathrm{CeO}_{2}$ or $\mathrm{La}_{2} \mathrm{O}_{3}$ can form a single or multi-layer nano-semiconductor layer on AC. From Table 2, when the loading of metal oxide was $10 \%$, the conversion of phenol was achieved $100 \%$ and $97.22 \%$ by using $3 \% \mathrm{Pd} / @-10 \% \mathrm{La}_{2} \mathrm{O}_{3} / \mathrm{AC}$ and 3\% $\mathrm{Pd} / @-10 \% \mathrm{CeO}_{2} / \mathrm{AC}$ as catalyst, respectively. The conversion of phenol was $72.12 \%$ when the loading of $\mathrm{CeO}_{2}$ was $5 \%$ (Table 2, entry 10), while the conversion decreased to $60.9 \%$ when $\mathrm{CeO}_{2}$ content was $1 \%$ (Table 2, entry 12). The $3 \% \mathrm{Pd} /$ (a)- $x \mathrm{La}_{2} \mathrm{O}_{3} / \mathrm{AC}$ catalyst was observed same result, the lower loading of $\mathrm{La}_{2} \mathrm{O}_{3}$, the lower conversion (Table 2, entry 15-18). Compared the 3\% Pd/@- $1 \% \mathrm{La}_{2} \mathrm{O}_{3} / \mathrm{AC}$ (Table 2, entry 18) with the $3 \% \mathrm{Pd} / \mathrm{AC}$ (Table 2, entry 1 ), it shown that add a few $\mathrm{La}_{2} \mathrm{O}_{3}$ could enhanced catalytic performance. The reason was that the nano- $\mathrm{La}_{2} \mathrm{O}_{3}$ improve the dispersity of the Pd particles, consistent with the result from the TEM images (Fig. 2e). But a few loading of $\mathrm{La}_{2} \mathrm{O}_{3}$ could not formed the rare-earth oxide layer, therefore Pd nanoparticles may be mostly supported on activated carbon directly rather than loaded on composite support with metal oxides. Moreover, Table 2 was also confirmed that a low loading of Pd was unfavorable for the formation of cyclohexanone. For $\mathrm{Pd} / @-\mathrm{CeO}_{2} / \mathrm{AC}$ catalyst, the phenol conversion decreased quickly from $97.22 \%$ (Table 2, entry 9) to $32.6 \%$ (Table 2, entry 7) when the loading of Pd from $3 \%$ to $1 \%$. For Pd/ (a)- $\mathrm{La}_{2} \mathrm{O}_{3} / \mathrm{AC}$ catalyst, the phenol conversion decreased from $100 \%$ (Table 2, entry 15 ) to $10.98 \%$ (Table 2 , entry 13 ) when the loading of Pd from $3 \%$ to $1 \%$.

These results also shown that the catalytic performance difference between 3\% Pd/@-10\% $\mathrm{La}_{2} \mathrm{O}_{3} / \mathrm{AC}$ and 3\% Pd/@-10\% $\mathrm{CeO}_{2} / \mathrm{AC}$, the possible reason could be attribute to the specific surface area. The specific surface area of 3\% Pd/@-10\% $\mathrm{La}_{2} \mathrm{O}_{3} /$

Table 3 Performance of 3\% Pd/ $-10 \% \mathrm{La}_{2} \mathrm{O}_{3} / \mathrm{AC}$ and $3 \% \mathrm{Pd} / \mathrm{a}-10 \% \mathrm{CeO}_{2} / \mathrm{AC}$ at different times, temperatures and $\mathrm{H}_{2}$ pressures ${ }^{a}$

\begin{tabular}{|c|c|c|c|c|c|c|c|}
\hline \multirow[b]{2}{*}{ Entry } & \multirow[b]{2}{*}{ Time (h) } & \multirow[b]{2}{*}{ Temperature $\left({ }^{\circ} \mathrm{C}\right)$} & \multirow[b]{2}{*}{$\mathrm{H}_{2}$ pressure $(\mathrm{MPa})$} & \multicolumn{2}{|l|}{$\mathrm{Pd} / @-\mathrm{La}_{2} \mathrm{O}_{3} / \mathrm{AC}$} & \multicolumn{2}{|l|}{$\mathrm{Pd} / @-\mathrm{CeO}_{2} / \mathrm{AC}$} \\
\hline & & & & Conversion (\%) & Selectivity (\%) & Conversion (\%) & Selectivity (\%) \\
\hline 1 & 3 & 50 & 0.7 & 52.26 & 96.79 & 42.62 & 95.35 \\
\hline 2 & 3 & 60 & 0.7 & 95.16 & 97.11 & 46.48 & 95.75 \\
\hline 3 & 1 & 70 & 0.7 & 55.34 & 98.11 & 43.25 & 96.51 \\
\hline 4 & 2 & 70 & 0.7 & 92.59 & 97.61 & 71.70 & 95.60 \\
\hline 5 & 3 & 70 & 0.7 & 100 & 96.82 & 98.28 & 96.33 \\
\hline 6 & 3 & 70 & 0.6 & 85.6 & 96.77 & 58.10 & 96.67 \\
\hline 7 & 3 & 70 & 0.5 & 79.14 & 97.3 & 45.32 & 96.70 \\
\hline
\end{tabular}

${ }^{a}$ Reaction conditions: phenol $(0.1 \mathrm{~g})$, catalyst $(0.353 \mathrm{~g}), n(\mathrm{Pd}) / n($ phenol $)=0.75 \%, \mathrm{CH}_{2} \mathrm{Cl}_{2}(20 \mathrm{~mL})$. 
Table 4 Performance of 3\% Pd/a-10\% $\mathrm{La}_{2} \mathrm{O}_{3} / \mathrm{AC}$ and 3\% $\mathrm{Pd} / \mathrm{a}-10 \% \mathrm{CeO}_{2} / \mathrm{AC}$ at different solvents ${ }^{a}$

\begin{tabular}{|c|c|c|c|c|c|c|c|}
\hline Time (h) & Solvent & \multicolumn{2}{|l|}{$\mathrm{Pd} / @-\mathrm{La}_{2} \mathrm{O}_{3} / \mathrm{AC}$} & TOF $\left(h^{-1}\right)$ & \multicolumn{2}{|l|}{$\mathrm{Pd} / @-\mathrm{CeO}_{2} / \mathrm{AC}$} & TOF $\left(h^{-1}\right)$ \\
\hline 3 & $\mathrm{H}_{2} \mathrm{O}$ & 54.13 & 96.29 & 24.01 & 35.27 & 96.70 & 15.64 \\
\hline 5 & $\mathrm{H}_{2} \mathrm{O}$ & 100 & 94.88 & 26.61 & 54.36 & 97.60 & 14.47 \\
\hline
\end{tabular}

${ }^{a}$ Reaction conditions: phenol $(0.1 \mathrm{~g})$, catalyst $(0.353 \mathrm{~g}), n(\mathrm{Pd}) / n(\mathrm{phenol})=0.75 \%, 70{ }^{\circ} \mathrm{C}, 0.7 \mathrm{MPa} \mathrm{H}_{2}$. Turnover frequency (TOF) defined as (mole of product $/($ moles of $\mathrm{Pd} \times$ reaction time $)$ ).

AC (1349.667 $\left.\mathrm{m}^{2} \mathrm{~g}^{-1}\right)$ was more than 3\% Pd/@-10\% $\mathrm{CeO}_{2} / \mathrm{AC}$ $\left(1138.102 \mathrm{~m}^{2} \mathrm{~g}^{-1}\right)$, so it was more beneficial to material transfer. The other reason can be find in TEM, the Pd particles of $3 \% \mathrm{Pd} /$ (a)-10\% $\mathrm{La}_{2} \mathrm{O}_{3} / \mathrm{AC}$ was more uniformly dispersed and more smaller than 3\% Pd/@-10\% $\mathrm{CeO}_{2} / \mathrm{AC}$. As we all know, the high dispersed noble metal catalyst often exhibit high catalytic performances.

In order to fully illustrate the superiority catalytic performance of the complex nanostructured catalysts, the catalytic performance of $\mathrm{Pd} / @-\mathrm{CeO}_{2} / \mathrm{AC}$ and $\mathrm{Pd} /$ @- $\mathrm{La}_{2} \mathrm{O}_{3} / \mathrm{AC}$ were investigated under various reaction conditions (Table 3 ). When reaction temperature increased from $50{ }^{\circ} \mathrm{C}, 60{ }^{\circ} \mathrm{C}$ to $70{ }^{\circ} \mathrm{C}$, the conversion of phenol increased quickly (Table 3 , entry 1, 2, 5). Increasing reaction temperature could made the reactant molecular energy increased and the activated molecule number continually increased, and accelerated the reaction rate. At the same time, it was indicated that a high $\mathrm{H}_{2}$ pressure was more favorable for the formation of cyclohexanone, the selectivity only declined slightly (Table 3 , entry $5,6,7$ ). Considered that the higher $\mathrm{H}_{2}$ pressure, the more $\mathrm{H}_{2}$ participated in reaction, the cyclohexanone could not quickly out of active site, then lead to further hydrogenation for cyclohexanol. Also, the results showed that phenol conversion increased quickly as the reaction time was extended from $1 \mathrm{~h}$ to $3 \mathrm{~h}$ (Table 3 , entry $3-5$ ).

Consider the environmental impact of the solvent, we also select $\mathrm{H}_{2} \mathrm{O}$ as a solvent, compared the performance of both $\mathrm{Pd}$ / (a- $\mathrm{CeO}_{2} / \mathrm{AC}$ and $\mathrm{Pd} /$ @- $\mathrm{La}_{2} \mathrm{O}_{3} / \mathrm{AC}$ under the same conditions, the results were shown in Table 4 . The phenol hydrogenation

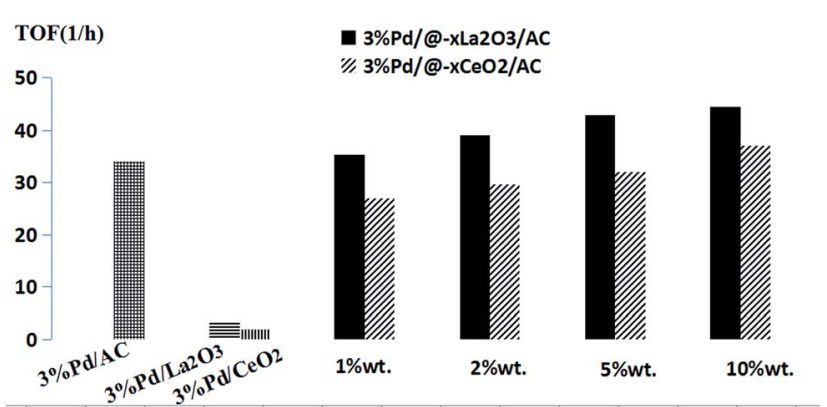

Fig. 4 The TOF of hydrogenation of phenol with the different catalysts. The $x$ represents the $\mathrm{CeO}_{2} / \mathrm{AC}$ and $\mathrm{La}_{2} \mathrm{O}_{3} / \mathrm{AC}$ loading by weight.

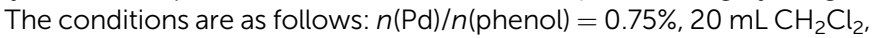
$70{ }^{\circ} \mathrm{C}, 0.7 \mathrm{MPa} \mathrm{H}_{2}, 3 \mathrm{~h}$. Turnover frequency (TOF) defined as (mole of product/(moles of $\mathrm{Pd} \times$ reaction time)). reaction used $\mathrm{CH}_{2} \mathrm{Cl}_{2}$ as a solvent was so much better than that of in $\mathrm{H}_{2} \mathrm{O}$. The conversion of phenol were only $54.13 \%$ and $35.27 \%$ in water within $3 \mathrm{~h}$ by $\mathrm{Pd} / @-\mathrm{La}_{2} \mathrm{O}_{3} / \mathrm{AC}$ and $\mathrm{Pd} / @-\mathrm{CeO}_{2} /$ $\mathrm{AC}$ catalyst, respectively. When the reaction time extends to $5 \mathrm{~h}$, the $\mathrm{Pd} /$ @- $\mathrm{La}_{2} \mathrm{O}_{3} / \mathrm{AC}$ catalyst catalyzed phenol totally conversion, we can inferred that phenol hydrogenation reaction in water instead of organic solvent should not be affected by mass transfer resistance and the phenol conversion will achieve $100 \%$ in water when the reaction time was enough long. But whether $\mathrm{Pd} / @-\mathrm{La}_{2} \mathrm{O}_{3} / \mathrm{AC}$ or $\mathrm{Pd} / @-\mathrm{CeO}_{2} / \mathrm{AC}$, the turnover frequency (TOF) in $\mathrm{H}_{2} \mathrm{O}$ was lower than it in $\mathrm{CH}_{2} \mathrm{Cl}_{2}$. The TOF of the $\mathrm{Pd} /$ @- $-\mathrm{La}_{2} \mathrm{O}_{3}$ / AC catalyst in $\mathrm{CH}_{2} \mathrm{Cl}_{2}$ could reach $44.35 \mathrm{~h}^{-1}$, and is higher than that of in $\mathrm{H}_{2} \mathrm{O}\left(24.01 \mathrm{~h}^{-1}\right)$. For $\mathrm{Pd} @-\mathrm{CeO}_{2} / \mathrm{AC}$ catalyst, the TOF in $\mathrm{CH}_{2} \mathrm{Cl}_{2}\left(36.98 \mathrm{~h}^{-1}\right)$ is also higher than that of in $\mathrm{H}_{2} \mathrm{O}$ $\left(15.64 \mathrm{~h}^{-1}\right)$. Because the catalysts were dispersed in $\mathrm{CH}_{2} \mathrm{Cl}_{2}$ preferably, and $\mathrm{H}_{2}$ had a better solubility, so phenol was easier adsorbed on the surface of catalysts for hydrogenate to cyclohexanone.

Fig. 4 illustrates the TOF obtained in the hydrogenation of phenol with the different catalysts (include different metal oxide loading) in $\mathrm{CH}_{2} \mathrm{Cl}_{2}$. The TOF of the $\mathrm{Pd} / @-\mathrm{La}_{2} \mathrm{O}_{3} / \mathrm{AC}$ catalysts was higher than $\mathrm{Pd} /$ @- $\mathrm{CeO}_{2} / \mathrm{AC}$ catalyst with different loading of rare-earth oxide as a whole. When the loading of rareearth oxide achieved $10 \%$, the TOF reached maximum, $3 \% \mathrm{Pd} /$ (a)-10\% $\mathrm{La}_{2} \mathrm{O}_{3} / \mathrm{AC}$ catalyst is $44.35 \mathrm{~h}^{-1}$ and $3 \% \mathrm{Pd} /$ @- $-10 \% \mathrm{CeO}_{2} /$ $\mathrm{AC}$ is $36.98 \mathrm{~h}^{-1}$. For $3 \% \mathrm{Pd} / \mathrm{La}_{2} \mathrm{O}_{3}$ and $3 \% \mathrm{Pd} / \mathrm{CeO}_{2}$, only 3.59 $\mathrm{h}^{-1}$ and $1.99 \mathrm{~h}^{-1}$ TOF were obtained under the same conditions, respectively. Less than one-tenth of the complex nanostructured catalysts. The TOF of $3 \% \mathrm{Pd} / \mathrm{AC}$ was $33.98 \mathrm{~h}^{-1}$, less than the $3 \% \mathrm{Pd} / @-10 \% \mathrm{La}_{2} \mathrm{O}_{3} / \mathrm{AC}$ or $3 \% \mathrm{Pd} / @-10 \% \mathrm{CeO}_{2} / \mathrm{AC}$. This result indicated that these novel nano-Pd complex catalysts were high efficient selective hydrogenation of phenol.

\subsection{Catalytic activity}

In Table 2, it was clear that the 3\% Pd/@-10\% $\mathrm{La}_{2} \mathrm{O}_{3} / \mathrm{AC}$ and $3 \%$ $\mathrm{Pd} / @-10 \% \mathrm{CeO}_{2} / \mathrm{AC}$ catalysts exhibited high efficient catalytic activity for hydrogenation of phenol to cyclohexanone. To further understand the catalytic performance of the complex nanostructured catalysts, $\mathrm{H}_{2}$-TPR of the catalysts and $\mathrm{AC}, 10 \%$ $\mathrm{CeO}_{2} / \mathrm{AC}, 10 \% \mathrm{La}_{2} \mathrm{O}_{3} / \mathrm{AC}, 3 \% \mathrm{Pd} / @-10 \% \mathrm{La}_{2} \mathrm{O}_{3} / \mathrm{AC}, 3 \% \mathrm{Pd} / @-10 \%$ $\mathrm{CeO}_{2} / \mathrm{AC}$ were carried out. The results are shown in Fig. 5. Two peaks at $462.1{ }^{\circ} \mathrm{C}$ and $663.5{ }^{\circ} \mathrm{C}$ in the AC sample could be attributed to the oxygen-containing functional groups like $-\mathrm{COOH},-\mathrm{OH},=\mathrm{O}$, which is a feature of carbon, etc. ${ }^{51}$ The reduction peak was observed at $556.2{ }^{\circ} \mathrm{C}$ over $\mathrm{CeO}_{2} / \mathrm{AC}$. For 




Fig. 5 TPR profiles of catalysts. (a) AC, (b) $\mathrm{CeO}_{2} / \mathrm{AC}$, (c) $\mathrm{Pd} / \mathrm{a}-\mathrm{CeO}_{2} /$ $\mathrm{AC},(d) \mathrm{La}_{2} \mathrm{O}_{3} / \mathrm{AC}$, (e) $\mathrm{Pd} /\left(\mathrm{a}-\mathrm{La}_{2} \mathrm{O}_{3} / \mathrm{AC}\right.$.

$\mathrm{CeO}_{2} / \mathrm{AC}$, the low temperature peak at $400-600{ }^{\circ} \mathrm{C}$ was due to the reduction of surface oxygen species attached to surface $\mathrm{Ce}^{4+}$ ions in an octahedral coordination. ${ }^{22} \mathrm{H}_{2}$-TPR of $\mathrm{La}_{2} \mathrm{O}_{3}$ /AC show one reduction peak at $643.1{ }^{\circ} \mathrm{C}$ that may be ascribed to the reduction of $\mathrm{La}_{2} \mathrm{O}_{3}$.

The TPR profiles of the $\mathrm{CeO}_{2} / \mathrm{AC}$ and $\mathrm{La}_{2} \mathrm{O}_{3} / \mathrm{AC}$ supported Pd catalysts changed significantly compared with those of $\mathrm{CeO}_{2} / \mathrm{AC}$ and $\mathrm{La}_{2} \mathrm{O}_{3} / \mathrm{AC}$. For $\mathrm{Pd} / @-\mathrm{CeO}_{2} / \mathrm{AC}$, there were two other reduction peaks at $175.1{ }^{\circ} \mathrm{C}$ and $603.5{ }^{\circ} \mathrm{C}$. The latter was ascribed to the reduction of the bulk oxygen of $\mathrm{CeO}_{2}$. The peak at $175.1{ }^{\circ} \mathrm{C}$ was assigned to the reduction of the species related to the $\mathrm{PdO}-\mathrm{CeO}_{2}$ interaction, which suggests that $\mathrm{PdO}$ is well-dispersed on the support and $\mathrm{CeO}_{2}$ interacts with $\mathrm{PdO} .{ }^{52}$ For $\mathrm{Pd} / @-\mathrm{La}_{2} \mathrm{O}_{3} / \mathrm{AC}$, there were two other reduction peaks at $172.9^{\circ} \mathrm{C}$ and $678.4^{\circ} \mathrm{C}$. The latter was ascribed to the reduction of the $\mathrm{La}_{2} \mathrm{O}_{3}$. The former was considered the reduction of PdO which was affected by $\mathrm{La}_{2} \mathrm{O}_{3}$. Such results are also shown that the reduction temperature of PdO in $\mathrm{Pd} / @-\mathrm{CeO}_{2} / \mathrm{AC}$ or $\mathrm{Pd} /$ @- $-\mathrm{La}_{2} \mathrm{O}_{3} / \mathrm{AC}$ shifts to a higher value compared with the individual $\mathrm{PdO}\left(50{ }^{\circ} \mathrm{C}\right)$. It is further demonstrated that the complex nanostructured catalysts exhibit synergistic effect of both nano-Pd and nano- $\mathrm{La}_{2} \mathrm{O}_{3} / \mathrm{AC}$ or nano-CeO $\mathrm{C}_{2} / \mathrm{AC}$.

\subsection{Compare with other catalyst}

To unveil the underlying factors that provide the superior activity of the hydrogenation over these complex nanostructured catalysts (Pd/@- $\mathrm{La}_{2} \mathrm{O}_{3} / \mathrm{AC}$ and $\left.\mathrm{Pd} / @-\mathrm{CeO}_{2} / \mathrm{AC}\right)$, we compared the TOF for the hydrogenation of phenol over these complex nanostructured catalysts with other catalysts in Table 5. The result shown that the $\mathrm{Pd} / @-\mathrm{La}_{2} \mathrm{O}_{3} / \mathrm{AC}$ catalyst catalytic the hydrogenation of phenol to cyclohexanone could be finished within $3 \mathrm{~h}$, with a TOF reaching over $44.35 \mathrm{~h}^{-1}$. TOF of the $\mathrm{Pd} / @-\mathrm{La}_{2} \mathrm{O}_{3} / \mathrm{AC}$ catalyst was about an order of magnitude higher than that of traditional catalysts and 2-ford higher than that of the best reported catalyst $\mathrm{Pd} / \mathrm{Al}_{2} \mathrm{O}_{3}$-CWE (Table 5, entry $3)$. It is illustrated that the complex nanostructured catalyst was an efficient catalytic system and exhibited outstanding activity and selectivity for phenol hydrogenation.

\subsection{Possible reaction mechanism of phenol over complex nanostructured catalysts}

In our study, the main product is cyclohexanone, a small amount of cyclohexanol (very slight). Generally, phenol was adsorbed by "non-planar" on alkaline support which was more advantage for the production of cyclohexanone. Whereas, it was more tend to produce cyclohexanol that phenol was adsorbed by "co-planar" on acidity support. ${ }^{28,57}$ As we all know, the adding of Ce or La could increase the alkaline of catalyst, then phenol was adsorbed by non-planar, inhibited the saturated hydrogenation of phenol to cyclohexanol. According to reaction results and the discussion above, possible reaction mechanism was proposed as the following. The process is shown in Scheme 3. The strong interaction between Pd and rare-earth oxide increases the ability to attract electron of hydroxyl group on phenol by non-planar, on which the $\mathrm{H}$ in the excited state could react on active benzene ring. After benzene ring hydrogenated to cyclohexanone, cyclohexanone was quickly dissociation of active site, otherwise it will further hydrogenation for cyclohexanol.

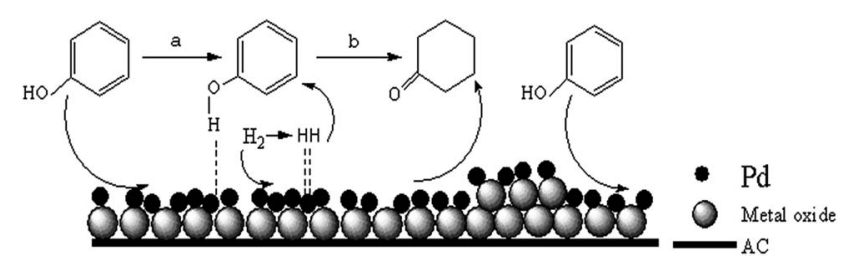

Scheme 3 Mechanism of phenol hydrogenation with catalysis of $\mathrm{Pd} /$ (a- $-\mathrm{CeO}_{2} / \mathrm{AC}$ or $\mathrm{Pd} / \mathrm{a}-\mathrm{La}_{2} \mathrm{O}_{3} / \mathrm{AC}$.

Table 5 Comparison of different catalysts for phenol hydrogenation ${ }^{a}$

\begin{tabular}{|c|c|c|c|c|c|c|c|c|}
\hline Entry & Catalyst & $n(\mathrm{Pd}): n($ phenol $)(\%)$ & $T\left({ }^{\circ} \mathrm{C}\right)$ & Time (h) & Conversion (\%) & Selectivity (\%) & TOF $\left(\mathrm{h}^{-1}\right)$ & Note \\
\hline 1 & $\mathrm{Pd} / @-\mathrm{La}_{2} \mathrm{O}_{3} / \mathrm{AC}$ & 0.75 & 70 & 3 & 100 & 96.82 & 44.35 & This work \\
\hline 2 & $\mathrm{Pd} / @-\mathrm{CeO}_{2} / \mathrm{AC}$ & 0.75 & 70 & 3 & 98.28 & 96.33 & 36.98 & This work \\
\hline 3 & $\mathrm{Pd} / \mathrm{Al}_{2} \mathrm{O}_{3}-\mathrm{CWE}$ & 2.5 & 100 & 2 & 100 & 98 & 20.05 & Ref. 53 \\
\hline 4 & $\mathrm{Pd} / \mathrm{TiO}_{2}-\mathrm{AC}$ & 1.6 & 50 & 4 & 47.3 & 96.4 & 15.27 & Ref. 54 \\
\hline 5 & Pd/MIL-101 & 1.8 & 50 & 4 & 99.6 & 80.3 & 13.52 & Ref. 55 \\
\hline 6 & $\mathrm{Pd} / \mathrm{SiO}_{2}$ & 2 & 60 & 7.5 & 99 & 97 & 6.32 & Ref. 56 \\
\hline 7 & Pd-HPW & 5 & 80 & 7 & $>99$ & $>99$ & 2.86 & Ref. 20 \\
\hline 8 & Pd-PANI/CNT & 5 & 80 & 9 & $>99.9$ & $>99$ & 2.22 & Ref. 18 \\
\hline
\end{tabular}

${ }^{a}$ Turnover frequency defined as (mole of product/(moles of $\mathrm{Pd} \times$ reaction time)). 


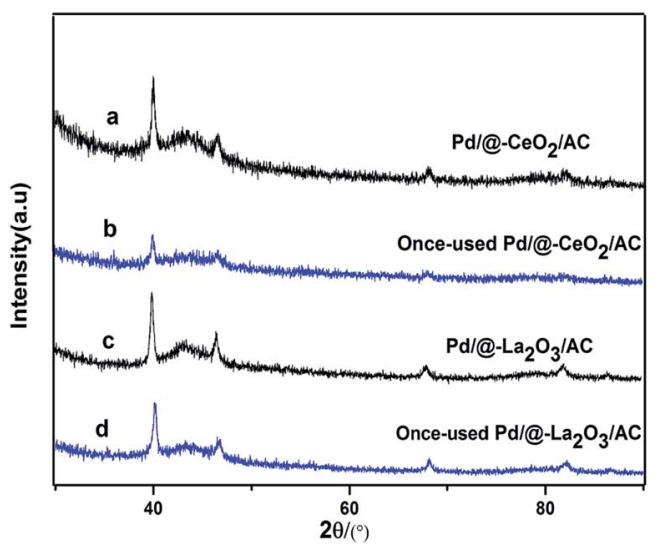

Fig. 6 The XRD patterns of catalysts, (a) $\mathrm{Pd} / \mathrm{a}-\mathrm{CeO}_{2} / \mathrm{AC}$, (b) once-used $\mathrm{Pd} /\left(\mathrm{a}-\mathrm{CeO}_{2} / \mathrm{AC}\right.$, (c) $\mathrm{Pd} /\left(\mathrm{a}-\mathrm{La}_{2} \mathrm{O}_{3} / \mathrm{AC}\right.$, (d) once-used $\mathrm{Pd} /\left(\mathrm{a}-\mathrm{La}_{2} \mathrm{O}_{3} / \mathrm{AC}\right.$.

After the reaction, the catalysts were recycled for phenol hydrogenation. The activity of $\mathrm{Pd} /\left(\mathrm{La}_{2} \mathrm{O}_{3} / \mathrm{AC}\right.$ and $\mathrm{Pd} / @-\mathrm{CeO}_{2} /$ AC were decreased. The XRD patterns of the once-used $\mathrm{Pd} /$ @- $\mathrm{La}_{2} \mathrm{O}_{3} / \mathrm{AC}$ and once-used $\mathrm{Pd} /$ @- $-\mathrm{CeO}_{2} / \mathrm{AC}$ were shown in Fig. 6. The Pd peaks of once-used catalysts were weakened, due to the destruction of the special structural and lost its portion activity component. Further study for the repeatability of the catalysts is still carried out.

\section{Conclusions}

Novel complex nanostructured catalysts $\mathrm{Pd} / @-\mathrm{La}_{2} \mathrm{O}_{3} / \mathrm{AC}$ and $\mathrm{Pd} /$ (a- $\mathrm{CeO}_{2} / \mathrm{AC}$ have been successfully fabricated via a photochemical route. The prepared catalysts $\mathrm{Pd} / @-\mathrm{La}_{2} \mathrm{O}_{3} / \mathrm{AC}$ and $\mathrm{Pd} /$ (a- $\mathrm{CeO}_{2} / \mathrm{AC}$ exhibited excellent performance of phenol hydrogenation under mild conditions. The results shown that $100 \%$ conversion of phenol and a selectivity higher than $96 \%$ were achieved within $3 \mathrm{~h}$ at $70{ }^{\circ} \mathrm{C}$ and $0.7 \mathrm{MPa}_{2}$ pressure, and the activity of Pd complex nanostructured catalyst was better than that of supported Pd on the metal oxide or AC directly. Furthermore, $\mathrm{H}_{2} \mathrm{O}$ was used as solvent, the prepared complex nanostructured catalysts also exhibited remarkable performance of phenol hydrogenation. It is indicated that the remarkable activity of these complex nanostructured catalysts may be ascribed to the synergistic effect of the interaction between active component nano-Pd and atom-layer rare-earth oxide, and enhance effect of electron of complex nanostructured catalysts, and formation of more contact interface due to the high dispersion of Pd particles on the large surface area support $\mathrm{La}_{2} \mathrm{O}_{3} / \mathrm{AC}$ and $\mathrm{CeO}_{2} / \mathrm{AC}$. This work demonstrated that novel complex nanostructured catalysts $\mathrm{Pd} / @-\mathrm{La}_{2} \mathrm{O}_{3} / \mathrm{AC}$ and $\mathrm{Pd} / @-\mathrm{CeO}_{2} / \mathrm{AC}$ prepared via a photochemical route exhibited synergistic catalysis of nano-Pd and rareearth oxide, and opened a new direction of complex nanostructured catalyst. The synergistic catalysis of complex nanostructured catalyst opened a promising direction to developing nanostructured catalyst for heterogeneous catalytic reaction.

\section{Conflicts of interest}

There are no conflicts to declare.

\section{Acknowledgements}

This work was supported by the Natural Science Foundation of China $(21676227,20976147)$, the Key Project of Hunan Provincial Natural Science Foundation of China (09JJ3021), the Key Laboratory Open Foundation of Higher Education Institutions of Hunan Province (12K047).

\section{References}

1 R. D. Patil and Y. Sasson, Appl. Catal., A, 2015, 499, 227-231. 2 X. Xuan, L. Haoran and W. Yong, ChemCatChem, 2015, 6, 3328-3332.

3 J. Hong, Q. Zhengyan, L. Ying, H. Jun, C. Rizhi and X. Weihong, Chem. Eng. J., 2016, 284, 724-732.

4 H. Shuo, Z. Xiang, Q. Zhengyan, J. Hong, L. Yefei, H. Jun, X. Weihong and C. Rizhi, J. Ind. Eng. Chem., 2017, 53, 333340 .

5 Z. Fengwei, C. Shuai, L. Huan, Z. Xianming and Y. Hengquan, RSC Adv., 2015, 5, 102811-102817.

6 M. Juan and C. Avelino, Appl. Catal., A, 2011, 404, 103-112.

7 N. Mahata, K. V. Raghavan, V. Vishwanathan, C. Parkb and M. A. Keane, Phys. Chem. Chem. Phys., 2001, 3, 2712-2719.

8 G. S. Sheldon, D. Errun, P. Colin and A. K. Mark, J. Mol. Catal. A: Chem., 2004, 212, 291-300.

9 W. Shingo and A. Venu, Top. Catal., 2010, 53, 1150-1152.

10 M. Kohsuke, F. Ken, O. Shusuke and Y. Hiromi, Chem. Commun., 2012, 48, 8886-8888.

11 Y. Hiroshi, N. Satomi, F. Shinichiro and A. Masahiko, J. Mol. Catal. A: Chem., 2013, 379, 80-85.

12 M. S. Priscilla, C. R. N. Raimundo, E. P. B. Luiz, J. Gary, H. D. Burtron, M. G. Uschi, E. R. Daniel and B. N. Fabio, ACS Catal., 2015, 5, 7385-7398.

13 G. Qingqing, Z. Yanhua, S. Junjun, C. XinSheng, G. Junjie, M. Rongrong, L. Bin and N. Ping, Chem. Eng. J., 2016, 299, 63-73.

14 K. Sergey, M. Anton, Z. Anna and K. Eduard, Catal. Commun., 2016, 73, 63-68.

15 L. Huizhen, J. Tao, H. Buxing, L. Shuguang and Z. Yinxi, Science, 2009, 326, 1250-1252.

16 W. Yong, Y. Jia, L. Haoran, S. Dangsheng and A. Markus, J. Am. Chem. Soc., 2011, 133, 2362-2365.

17 Z. Mengsi, S. Juanjuan and H. Zhaoyin, Chin. J. Catal., 2016, 37, 234-239.

18 C. Jinzhu, Z. Wei, C. Limin, M. Longlong, G. Hui and W. Tiejun, ChemPlusChem, 2013, 78, 142-148.

19 C. Aibing, L. Yonglei, C. Jinzhu, Z. Guoying, M. Longlong and Y. Yifeng, ChemPlusChem, 2013, 78, 1370-1378.

20 C. Aibing, Z. Guoying, C. Jinzhu, C. Limin and Y. Yifeng, RSC Adv., 2013, 3, 4171-4175.

21 X. Guangyue, G. Jianhua, Y. Zhang, Y. Fu, C. Jinzhu, M. Longlong and G. Qingxiang, ChemCatChem, 2015, 7, 2485-2492.

22 Y. Ye, W. Zhimiao, A. Hualiang, X. Wei and W. Yanji, Chin. J. Catal., 2015, 36, 1142-1154.

23 L. Lianjun, C. Yuan, S. Wenjing, Y. Zhijian, L. Bin, G. Fei and D. Lin, Catal. Today, 2011, 175, 48-54. 
24 W. Zili, L. Meijun and H. O. Steven, J. Catal., 2012, 285, 6173.

25 C. N. Nicholas, J. M. Sebastián, D. S. Aaron, H. O. Steven and I. S. Igor, ACS Catal., 2015, 5, 2051-2061.

26 K. SangWoo and R. ShiWoo, J. Electrochem. Soc., 2002, 6, C345-C348.

27 S. Salvatore, M. Simona and C. Carmelo, Appl. Catal., A, 2002, 235, 21-31.

28 S. Velu, M. P. Kapoor, S. Inagaki and K. Suzuki, Appl. Catal., A, 2003, 245, 317-331.

29 Q. Fu, H. Saltsburg and M. Flytzani-Stephanopoulos, Science, 2003, 301, 935-938.

30 F. Qi, W. Deng, H. Saltsburg and M. FlytzaniStephanopoulos, Appl. Catal., B, 2005, 56, 57-68.

31 Y. Ming, L. F. Allard and F. S. Maria, J. Am. Chem. Soc., 2013, 135, 219-224.

32 Q. Botao, W. Aiqin, Y. Xiaofeng, L. F. Allard, J. Zheng, C. Yitao, L. Jingyue, L. Jun and Z. Tao, Nat. Chem., 2011, 3, 634-641.

33 L. Jian, W. Aiqin, Q. Botao, L. Xiaoyan, Y. Xiaofeng, W. Xiaodong, L. Jinxia, L. Jun, L. Jingyue and Z. Tao, J. Am. Chem. Soc., 2013, 135, 15314-15317.

34 Y. XiaoFeng, W. Aiqin, Q. Botao, L. Jun, L. Jingyue and Z. Tao, Acc. Chem. Res., 2013, 46, 1740-1748.

35 Z. Jicheng, Y. Xiaofeng, W. Yaqiong and C. Weijun, Catal. Commun., 2014, 46, 228-233.

36 L. Lin, Z. Jicheng, X. Zhibo and O. Wenbing, Acta Pet. Sin., 2013, 29, 975-983.

37 W. Yaqing, Z. Jicheng and Y. Xiaofeng, Chin. J. Process Eng., 2009, 6, 1186-1191.

38 G. Glaspell, L. Fuoco and M. S. El-Shall, J. Phys. Chem. B, 2005, 37, 17350-17355.

39 S. F. Chen, J. P. Li and K. Qian, Nano Res., 2010, 3, 244-255. 40 P. Liu, Y. Zhao, R. Qin, S. Mo, G. Chen, L. Gu, D. M. Chevrier, P. Zhang, Q. Guo, D. Zang, B. Wu, G. Fu and N. Zheng, Science, 2016, 352(6287), 797.
41 H. Gu, Y. Yang, J. Tian and G. Shi, ACS Appl. Mater. Interfaces, 2013, 5, 6762-6768.

42 G. K. Lau, T. S. Zhang and G. K. L. Goh, J. Nanosci. Nanotechnol., 2010, 10, 4733-4737.

43 X. L. Seoane, N. S. Figoli, P. C. L'Argentiere, J. A. Gonzalez and A. Arcoya, Catal. Lett., 1997, 47, 213-220.

44 S. Zheng and L. Gao, Mater. Chem. Phys., 2002, 78, 512-517; S. A. Khan and A. Ahmad, Mater. Res. Bull., 2013, 48, 41344138.

45 R. V. Gulyaev, E. M. Slavinskaya, S. A. Novopashin, D. V. Smovzh, A. V. Zaikovskii, D. Y. Osadchii, O. A. Bulavchenko, S. V. Korenev and A. I. Boronin, Appl. Catal., B, 2014, 147, 132-143.

46 D. Shuaishuai, Z. Chunhua, L. Yefei, J. Hong, X. Weihong and C. J. Rizhi, Ind. Eng. Chem., 2017, 46, 258-265.

47 E. A. Anumol, P. Kundu, P. A. Deshpande, G. Madras and N. Ravishankar, ACS Nano, 2011, 5, 8049-8061.

48 H. Spod, M. Lucas and P. Claus, ChemCatChem, 2016, 8, 1-9. 49 L. Yi, X. Xuan, Z. Pengfei, G. Yutong, L. Haoran and W. Yong, RSC Adv., 2013, 3, 10973-10982.

50 L. Hui, L. Jianliang and L. Hexing, Mater. Lett., 2008, 62, 297300.

51 L. Hui, L. Jun, X. Songhai, Q. Minghua, D. Weilin, L. Yunfeng and L. Hexing, Adv. Funct. Mater., 2008, 18, 3235-3241.

52 S. Chandra Shekar, J. Krishna Murthy, P. Kanta Rao and K. S. Rama Rao, J. Mol. Catal. A: Chem., 2003, 191, 45-59.

53 Z. Huaqing, Q. Zhangfeng, S. Wenjuan, S. Wenjie and W. Jianguo, J. Catal., 2004, 225, 267-277.

54 Y. Pérez, M. Fajardo and A. Corma, Catal. Commun., 2011, 12, 1071-1074.

55 Z. Damin, Y. Feiyang, X. Teng, G. Yejun and W. Yi Meng, Catal. Today, 2014, 234, 133-138.

56 C. Ling, D. Qiguang, L. Hua and W. Xingyi, Catal. Commun., 2014, 57, 23-28.

57 Y. Z. Chen, C. W. Liaw and L. I. Lee, Appl. Catal., A, 1999, 177, 1-8. 